\title{
Devosia psychrophila sp. nov. and Devosia glacialis sp. nov., from alpine glacier cryoconite, and an emended description of the genus Devosia
}

Correspondence
Rosa Margesin
Rosa.Margesin@uibk.ac.at

\author{
De-Chao Zhang, ${ }^{1}$ Mersiha Redzic, ${ }^{1}$ Hong-Can Liu, ${ }^{2}$ Yu-Guang Zhou, ${ }^{2}$ \\ Franz Schinner ${ }^{1}$ and Rosa Margesin ${ }^{1}$
}

\author{
${ }^{1}$ Institute of Microbiology, University of Innsbruck, Technikerstrasse 25, A-6020 Innsbruck, Austria \\ ${ }^{2}$ China General Microbiological Culture Collection Center and State Key Laboratory of Microbial \\ Resources, Institute of Microbiology, Chinese Academy of Sciences, Beijing 100101, PR China
}

The genus Devosia falls within the class Alphaproteobacteria (Nakagawa et al., 1996) and was created by the reclassification of 'Pseudomonas riboflavina' (Foster, 1944) as Devosia riboflavina (Nakagawa et al., 1996). The genus accommodates Gram-negative, rod-shaped, obligately aerobic, oxidase-positive bacteria and contains Q-10 or Q-11 as the predominant respiratory quinone. The fatty acid profile consists of unsaturated and straight-chain fatty acids, 11methyl $\mathrm{C}_{18: 1} \omega 7 c$ and hydroxy or branched fatty acids. The DNA G + C content ranges from 59.5 to $66.2 \mathrm{~mol} \%$ (Nakagawa et al., 1996; Yoon et al., 2007). At the time of writing, 11 species and three uncultured Devosia strains with the provisional name 'Candidatus Devosia euplotis' (Vannini et al., 2004) have been described within the genus. The culturable species of the genus have been isolated from a variety of sources including nodules of

The GenBank/EMBL/DDBJ accession numbers for the 16S rRNA gene sequences of strains $\mathrm{Cr} 7-05^{\top}$ and $\mathrm{Cr} 4-44^{\top}$ are GU441678 and HM474794, respectively.

Three supplementary figures and a supplementary table are available with the online version of this paper. legume plants (Rivas et al., 2003; Bautista et al., 2010), a nitrifying inoculum (Vanparys et al., 2005), soil (Yoo et al., 2006; Yoon et al., 2007; Kumar et al., 2008; Ryu et al., 2008; Verma et al., 2009) and beach sediment (Lee, 2007). The uncultured 'Candidatus D. euplotis' strains were endosymbionts of a marine ciliate (Vannini et al., 2004). Some representatives of the genus Devosia are able to grow at $5{ }^{\circ} \mathrm{C}$ (Kumar et al., 2008; and results from this study); however, members of the genus have not yet been described from cold regions. In this study, we report the characterization of two psychrophilic bacterial strains, designated $\mathrm{Cr} 7-05^{\mathrm{T}}$ and $\mathrm{Cr} 4-44^{\mathrm{T}}$, isolated from alpine glacier cryoconite that was sampled at different geographical locations.

Strain $\mathrm{Cr} 7-05^{\mathrm{T}}$ was isolated from alpine glacier cryoconite collected from the Pitztaler Jöchl glacier in the Oetztaler Alps in Tyrol, Austria, at an altitude of $2875 \mathrm{~m}$ above sea level ( $\left.46^{\circ} 56^{\prime} 31.22^{\prime \prime} \mathrm{N} 10^{\circ} 55^{\prime} 20.15^{\prime \prime} \mathrm{E}\right)$, as described by Zhang et al. (2011). Strain Cr4-44 ${ }^{\mathrm{T}}$ was isolated from cryoconite collected from the Pasterze glacier/Großglockner in the Hohe Tauern, Austria, at an altitude of $2200 \mathrm{~m}$ above 


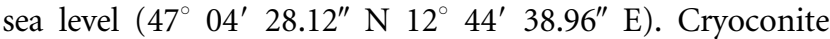
samples were collected under sterile conditions in spring 2006. Part of the sample ( $1 \mathrm{~g}$ dry mass) was shaken with $9 \mathrm{ml}$ sterile $1 \%$ sodium pyrophosphate for $20 \mathrm{~min}$ at 150 r.p.m. Appropriate dilutions, prepared with sterile saline solution $(0.9 \% \mathrm{NaCl})$, were plated on $\mathrm{R} 2 \mathrm{~A}$ agar plates (Reasoner \& Geldreich, 1985$)(0.05 \%$ yeast extract, $0.05 \%$ peptone, $0.05 \%$ Casamino acids, $0.05 \%$ glucose, $0.05 \%$ starch, $0.03 \%$ sodium pyruvate, $0.03 \% \mathrm{~K}_{2} \mathrm{HPO}_{4}, 0.005 \% \mathrm{MgSO}_{4}, 1.5 \%$ agar, $\mathrm{pH}$ 7) that were incubated at $10{ }^{\circ} \mathrm{C}$. Devosia limi DSM $17137^{\mathrm{T}}$, Devosia chinhatensis CCM $7426^{\mathrm{T}}$ and Devosia subaequoris KCTC $12772^{\mathrm{T}}$ were used as reference strains and were routinely grown on R2A agar plates at $20{ }^{\circ} \mathrm{C}$.

DNA was extracted and purified as described by Sambrook et al. (1989). The $16 \mathrm{~S}$ rRNA gene was amplified by PCR with universal primers 27F (5'-AGAGTTTGATCCTGGCTCAG$\left.3^{\prime}\right)$ and 1541R (5'-AAGGAGGTGATCCAGCCGCA-3'). PCR products were cloned by using pGEM-T vectors (Promega) according to the manufacturer's instructions. On the basis of pairwise comparisons of 16S rRNA gene sequences using the EzTaxon program (Chun et al., 2007), strains $\mathrm{Cr} 7-05^{\mathrm{T}}$ and $\mathrm{Cr} 4-44^{\mathrm{T}}$ exhibited $16 \mathrm{~S}$ rRNA gene sequence similarity of 94.7-97.2 and 94.9-96.9\%, respectively, with respect to the type strains of recognized Devosia species. The 16S rRNA gene sequence similarity between strains $\mathrm{Cr} 7-05^{\mathrm{T}}$ and $\mathrm{Cr} 4-44^{\mathrm{T}}$ was $98.6 \%$. The type strain of Devosia riboflavina, the type species of the genus, shared relatively low $16 \mathrm{~S}$ rRNA gene sequence similarity with strain Cr7-05 ${ }^{\mathrm{T}}(96.6 \%)$ and strain Cr4-44 ${ }^{\mathrm{T}}(96.5 \%)$. Phylogenetic analysis was performed using the MEGA 4.0 software (Tamura et al., 2007) and the PHYLIP 3.69 package (Felsenstein, 2009) after multiple alignment of data using ClUSTAL X version 1.8 (Thompson et al., 1997). For neighbour-joining analysis (Saitou \& Nei, 1987), genetic distances were calculated using Kimura's two-parameter model (Kimura, 1980). Phylogenetic analysis based on the neighbour-joining method showed that the two strains formed a coherent cluster at a bootstrap resampling value of $90 \%$ and also formed a distinct phyletic line in the clade of D. limi DSM $17137^{\mathrm{T}}$ and 'Candidatus D. euplotis' in the neighbour-joining tree (Fig. 1). The relative position of strains $\mathrm{Cr} 7-05^{\mathrm{T}}$ and $\mathrm{Cr} 4-44^{\mathrm{T}}$ was also confirmed in the maximum-likelihood tree.

To find the 16S rRNA sequence signatures that distinguish the genus Devosia from other taxa in the phylum Proteobacteria (Nakagawa et al., 1996), we aligned the sequences of strains $\mathrm{Cr} 7-05^{\mathrm{T}}$ and $\mathrm{Cr} 4-44^{\mathrm{T}}$. Nucleotide signatures specific to the $16 \mathrm{~S}$ rRNA gene sequence of strains $\mathrm{Cr} 7-05^{\mathrm{T}}$ and $\mathrm{Cr} 4-44^{\mathrm{T}}$ were the same as those reported by Nakagawa et al. (1996) for the genus Devosia, except that the signature sequence at positions 445:489 and 1419: 1481 was G-C instead of A-U (Escherichia coli numbering; Brosius et al., 1978; Kumar et al., 2008).

Strains $\mathrm{Cr} 7-05^{\mathrm{T}}$ and $\mathrm{Cr} 4-44^{\mathrm{T}}$ were routinely cultured on R2A agar plates at $20{ }^{\circ} \mathrm{C}$ and maintained as a suspension in skimmed milk $\left(10 \%\right.$, w/v) at $-80{ }^{\circ} \mathrm{C}$. Cell morphology was studied by phase-contrast microscopy $(\times 1000)$ and by transmission electron microscopy (Zeiss Libra 120 EFTEM) of cells grown on R2A agar plates at $20{ }^{\circ} \mathrm{C}$. Motility was examined by microscopy $(\times 1000)$, by the API $M$ system (bioMérieux) and by the DSMZ on soft agar. Colony morphology was observed on R2A agar plates that were incubated at $20{ }^{\circ} \mathrm{C}$.

The tests described in this paragraph were done with strains $\mathrm{Cr} 7-05^{\mathrm{T}}$ and $\mathrm{Cr} 4-44^{\mathrm{T}}$ and all three reference strains (D. limi DSM $17137^{\mathrm{T}}$, D. chinhatensis CCM $7426^{\mathrm{T}}$ and $D$. subaequoris KCTC $12772^{\mathrm{T}}$ ). Gram staining was performed by using the bioMérieux Gram stain kit. Catalase activity was determined by bubble production in $3 \%(\mathrm{v} / \mathrm{v}) \mathrm{H}_{2} \mathrm{O}_{2}$

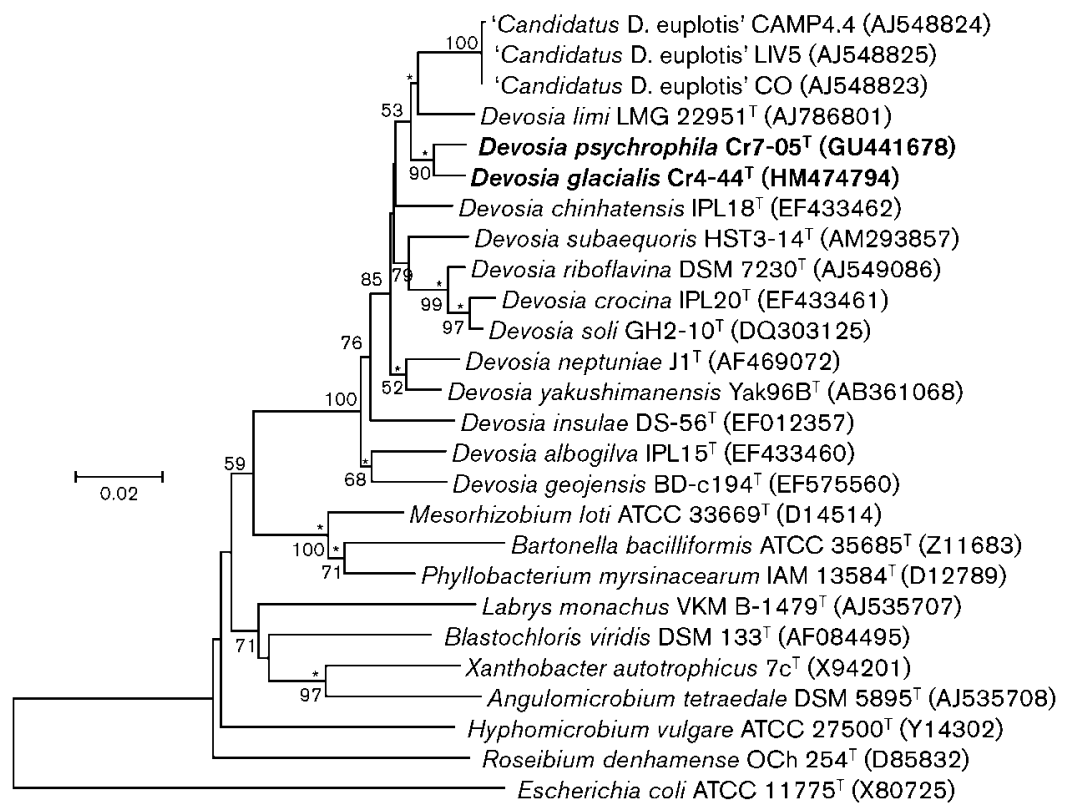

Fig. 1. Neighbour-joining tree, based on 16S rRNA gene sequence data, showing the phylogenetic positions of strains $\mathrm{Cr} 7-05^{\top}$ and Cr4-44 $4^{\top}$, recognized members of the genus Devosia and representatives of some related taxa. The sequence of Escherichia coli ATCC $11775^{\top}$ was used as an outgroup. Asterisks indicate nodes that were also found in the maximum-likelihood tree. Bootstrap values (\%) are based on 1000 replicates and are shown for branches with more than $50 \%$ support. GenBank accession numbers are given in parentheses. Bar, $2 \%$ sequence divergence. 
and oxidase activity was determined using $1 \%(\mathrm{w} / \mathrm{v})$ $N, N, N^{\prime} N^{\prime}$-tetramethyl-p-phenylenediamine. API $20 \mathrm{E}$, API $20 \mathrm{NE}$ and API ZYM strips (bioMérieux) incubated at $20{ }^{\circ} \mathrm{C}$ for $20 \mathrm{~h}$ (API ZYM) or 7 days (API $20 \mathrm{E}$, API $20 \mathrm{NE}$ ) were used to determine physiological and biochemical characteristics as well as enzyme activities. Activities of $\beta$ galactosidase, amylase, lipase and protease were additionally tested by using R2A agar plates supplemented with appropriate substrates (Margesin et al., 2003). Growth at $1-37{ }^{\circ} \mathrm{C}$ was assessed on R2A agar plates and in R2A liquid medium at 150 r.p.m. Growth at $\mathrm{pH}$ 5-9 and tolerance of $0-10 \%(\mathrm{w} / \mathrm{v}) \mathrm{NaCl}$ were determined on R2A agar plates. The features that serve to differentiate strains $\mathrm{Cr} 7-05^{\mathrm{T}}$ and $\mathrm{Cr} 4-44^{\mathrm{T}}$ from the phylogenetically most closely related members of the genus Devosia are given in Table 1 . Morphological, physiological and biochemical characteristics of strains $\mathrm{Cr} 7-05^{\mathrm{T}}$ and $\mathrm{Cr} 4-44^{\mathrm{T}}$ are given in the species descriptions or are shown in Table 1.

Respiratory quinones were extracted and purified according to Collins (1985) and were analysed by HPLC (Wu et al., 1989). Strains Cr7- $05^{\mathrm{T}}$ and $\mathrm{Cr} 4-44^{\mathrm{T}}$ contained Q-10 as the predominant ubiquinone.

Cellular polar lipids were extracted and analysed on silica gel plates (Kieselgel 60 F; Merck) by TLC (Kates, 1986).
Strains $\mathrm{Cr} 7-05^{\mathrm{T}}$ and $\mathrm{Cr} 4-44^{\mathrm{T}}$ showed the presence of some polar lipids in common, including diphosphatidylglycerol, phosphatidylglycerol, three unknown glycolipids (GL1-3) and two unknown polar lipids (PL1-2) (Supplementary Fig. S1, available in IJSEM Online). However, the polar lipid pattern of strain Cr7- $05^{\mathrm{T}}$ could be distinguished from that of strain $\mathrm{Cr} 4-44^{\mathrm{T}}$ by the presence of GL4-5 and more unknown polar lipids. Though the polar lipids of Devosia geojensis and D. yakushimensis have been analysed (Ryu et al., 2008; Bautista et al., 2010), no images of the polar lipid profiles were shown and the profiles are therefore not accessible for visual comparison. The presence of GL1-5 in extracts from strain Cr7- $05^{\mathrm{T}}$ and GL1-3 in extracts from strain $\mathrm{Cr} 4-44^{\mathrm{T}}$ enabled the two strains to be differentiated from D. geojensis and D. yakushimensis.

For fatty acid methyl ester analysis, strains $\mathrm{Cr} 7-05^{\mathrm{T}}$ and Cr4- $44^{\mathrm{T}}$ and the reference strains $D$. limi DSM $17137^{\mathrm{T}}, D$. chinhatensis CCM $7426^{\mathrm{T}}$ and D. subaequoris KCTC $12772^{\mathrm{T}}$ were grown on R2A agar plates at $20{ }^{\circ} \mathrm{C}$ for 3 days. Fatty acid methyl esters were extracted and prepared according to the standard protocol of the Sherlock Microbial Identification System (MIDI, version 6.0) (Sasser, 1990) and were identified using the database TSBA (version 6.0). The predominant cellular fatty acids of strain $\mathrm{Cr} 7-05^{\mathrm{T}}$ were

Table 1. Phenotypic characteristics that differentiate strains $\mathrm{Cr} 7-05^{\top}$ and $\mathrm{Cr} 4-44^{\top}$ from phylogenetically closely related Devosia species and the type species of the genus Devosia

Strains: 1, Devosia psychrophila sp. nov. Cr7-05 $5^{\mathrm{T}} ; 2$, Devosia glacialis sp. nov. Cr4-44 ${ }^{\mathrm{T}} ; 3$, D. limi DSM $17137^{\mathrm{T}} ; 4$, D. chinhatensis CCM $7426^{\mathrm{T}} ; 5$, D. subaequoris KCTC $12772^{\mathrm{T}}$; 6, D. riboflavina IFO $13584^{\mathrm{T}}$ (data from Nakagawa et al., 1996; Yoon et al., 2007). Data were obtained in this study unless indicated. +, Positive; -, negative; $\mathrm{W}$, weak; ND, no data available. All strains are positive for motility and for activities of acid and alkaline phosphatases, esterase (C4), esterase lipase (C8), leucine arylamidase, $N$-acetyl- $\beta$-glucosaminidase, naphthol-AS-BI-phosphohydrolase, $\beta$ galactosidase and $\beta$-glucosidase. All strains are negative for indole production, arginine dihydrolase, gelatin hydrolysis and $\beta$-glucuronidase. All strains are negative for assimilation of citrate, malic acid, capric acid, adipic acid and phenylacetic acid and for fermentation of D-glucose, Dmannitol, sucrose and inositol.

\begin{tabular}{|c|c|c|c|c|c|c|}
\hline Characteristic & 1 & 2 & 3 & 4 & 5 & 6 \\
\hline Isolation source & Glacier cryoconite & Glacier cryoconite & Nitrifying inoculum & Soil & Beach sediment & Soil \\
\hline Colony colour & White & Light pink & White & White & White & Cream \\
\hline \multicolumn{7}{|c|}{ Growth at/in the presence of/on: } \\
\hline $1{ }^{\circ} \mathrm{C}$ & + & + & $\mathrm{W}$ & - & - & ND \\
\hline $5{ }^{\circ} \mathrm{C}$ & + & + & + & - & - & $\mathrm{ND}$ \\
\hline $30{ }^{\circ} \mathrm{C}$ & - & - & + & + & + & + \\
\hline $3 \%(w / v) \mathrm{NaCl}$ & - & - & + & + & + & $\mathrm{ND}$ \\
\hline $\mathrm{pH} 6$ & - & $\mathrm{W}$ & + & $\mathrm{w}$ & - & $\mathrm{ND}$ \\
\hline Nutrient agar & $\mathrm{w}$ & - & + & $\mathrm{w}$ & - & + \\
\hline Nitrate reduction & - & + & - & + & + & + \\
\hline Catalase activity & - & + & + & + & - & + \\
\hline Urease activity & - & + & + & + & + & + \\
\hline \multicolumn{7}{|c|}{ Assimilation of (API $20 \mathrm{NE}$ ): } \\
\hline D-Glucose & + & - & - & + & + & + \\
\hline L-Arabinose & + & - & - & + & + & + \\
\hline D-Mannose & + & - & - & + & + & + \\
\hline D-Mannitol & + & - & - & + & + & + \\
\hline $\mathrm{N}$-Acetylglucosamine & + & - & - & + & + & + \\
\hline Maltose & + & - & - & + & + & + \\
\hline
\end{tabular}


$\mathrm{C}_{18: 1} \omega 7 c(43.9 \%)$, summed feature $3\left(\mathrm{C}_{16: 1} \omega 7 c\right.$ and/or $\left.\mathrm{C}_{16: 1} \omega 6 c\right)(21.7 \%), \mathrm{C}_{16: 0}$ (7.5\%), 11-methyl $\mathrm{C}_{18: 1} \omega 7 c$ $(6.3 \%)$ and $\mathrm{C}_{18: 0}(5.2 \%)$, and those of strain $\mathrm{Cr} 4-44^{\mathrm{T}}$ were $\mathrm{C}_{18: 1} \omega 7 c(47.2 \%)$, summed feature $3\left(\mathrm{C}_{16: 1} \omega 7 c\right.$ and/or $\left.\mathrm{C}_{16: 1} \omega 6 c\right)(20.3 \%), \mathrm{C}_{16: 0}(14.8 \%)$ and $\mathrm{C}_{14: 0}(7.2 \%)$. Thus, the fatty acid profiles of strains $\mathrm{Cr} 7-05^{\mathrm{T}}$ and $\mathrm{Cr} 4-44^{\mathrm{T}}$ resembled those of other Devosia species (Rivas et al., 2003; Yoon et al., 2007; Lee, 2007), with the exception that the two strains contained larger amounts of the unsaturated fatty acid summed feature $3\left(\mathrm{C}_{16: 1} \omega 7 c\right.$ and/or $\left.\mathrm{C}_{16: 1} \omega 6 c\right)$ compared with other Devosia species. Details of the fatty acid profiles of strains $\mathrm{Cr} 7-05^{\mathrm{T}}$ and $\mathrm{Cr} 4-44^{\mathrm{T}}$ and the reference strains are available in Supplementary Table S1.

The DNA $\mathrm{G}+\mathrm{C}$ content was determined by the thermal denaturation method with Escherichia coli $\mathrm{K}-12$ as the reference, and DNA-DNA hybridization was done by the liquid renaturation method (De Ley et al., 1970) as modified by Huß et al. (1983). Both experiments were carried out using a model Lambda $35 \mathrm{UV} / \mathrm{Vis}$ spectrometer equipped with a temperature program controller (Perkin-Elmer). The DNA $\mathrm{G}+\mathrm{C}$ contents of strains $\mathrm{Cr} 7-05^{\mathrm{T}}$ and $\mathrm{Cr} 4-44^{\mathrm{T}}$ were 61.4 and $63.6 \mathrm{~mol} \%$, respectively. The DNA-DNA relatedness between strain $C r 7-05^{\mathrm{T}}$ and D. limi DSM $17137^{\mathrm{T}}$ was $37.3 \%$, and that between isolates $\mathrm{Cr} 7-05^{\mathrm{T}}$ and $\mathrm{Cr} 4-44^{\mathrm{T}}$ was $54.1 \%$. Thus, both DNA-DNA relatedness values are lower than the hybridization threshold $(70 \%)$ recommended for species delineation (Wayne et al., 1987). 16S rRNA gene sequence similarities $<97.0 \%$ were found with other recognized species of the genus Devosia. According to Stackebrandt \& Goebel (1994), bacterial strains with less than $97 \% 16 \mathrm{~S}$ rRNA gene sequence similarity exhibit levels of DNA-DNA hybridization that are less than $70 \%$. Therefore, we can conclude that strains Cr7$05^{\mathrm{T}}$ and $\mathrm{Cr} 4-44^{\mathrm{T}}$ are genotypically distinct from all other species of the genus Devosia.

The data presented in this study demonstrate that strains Cr7$05^{\mathrm{T}}$ and $\mathrm{Cr} 4-44^{\mathrm{T}}$ are psychrophilic members of the genus Devosia. We use the term 'psychrophile' as a general term to describe a micro-organism that grows in a cold environment (Margesin et al., 2008); the use of growth rates to define the optimum growth temperature as described by Morita (1975) has been shown to be ambiguous and inappropriate (Feller \& Gerday 2003; Cavicchioli, 2006; Margesin, 2009).

The two isolates described in this study showed differences in terms of polar lipid patterns, nitrate reduction, urease activity and assimilation of a range of carbon sources, and their colonies differed in colour (Table 1). Both isolates can be easily differentiated from their closest phylogenetic neighbours (D. limi DSM $17137^{\mathrm{T}}$, D. chinhatensis CCM $7426^{\mathrm{T}}$ and D. subaequoris KCTC $12772^{\mathrm{T}}$ ) by their psychrophilic growth characteristics (weak growth at $25{ }^{\circ} \mathrm{C}$ and absence of growth at $30^{\circ} \mathrm{C}$; ability to grow at $1{ }^{\circ} \mathrm{C}$, in contrast to $D$. chinhatensis $\mathrm{CCM} 7426^{\mathrm{T}}$ and $D$. subaequoris KCTC $12772^{\mathrm{T}}$, and faster growth at $1{ }^{\circ} \mathrm{C}$ compared with $D$. limi DSM $17137^{\mathrm{T}}$ ), their inability to grow in the presence of $3 \%(\mathrm{w} / \mathrm{v}) \mathrm{NaCl}$ and the relative amounts of certain cellular fatty acids (summed feature 3). Based on phenotypic, phylogenetic and genomic data, it is evident that strains Cr7- $05^{\mathrm{T}}$ and $\mathrm{Cr} 4-44^{\mathrm{T}}$ represent separate novel species of the genus Devosia, for which the names Devosia psychrophila sp. nov. and Devosia glacialis sp. nov., respectively, are proposed.

\section{Emended description of the genus Devosia Nakagawa et al. 1996}

The description is as given by Nakagawa et al. (1996) and emended by Rivas et al. (2003), Yoo et al. (2006) and Yoon et al. (2007), with the following further amendments. Cells are positive or negative for catalase and urease. Pigmentation of colonies on R2A agar plates differs between species. Major polar lipids are diphosphatidylglycerol, phosphatidylglycerol and unknown glycolipids.

\section{Description of Devosia psychrophila sp. nov.}

Devosia psychrophila (psy.chro'phi.la. Gr. adj. psychros cold; Gr. adj. philos liking, loving; N.L. fem. adj. psychrophila cold-loving).

Cells are aerobic, Gram-staining-negative, motile (polar flagellation; Supplementary Fig. S2) and rod-shaped (0.4$0.6 \times 1.0-1.5 \mu \mathrm{m}$ after 2 days and $0.4-0.6 \times 4-5 \mu \mathrm{m}$ after 7 days at $20{ }^{\circ} \mathrm{C}$ on $\mathrm{R} 2 \mathrm{~A}$ agar plates). Colonies on R2A agar are white, convex, smooth and round with entire margins and produce slime. Colony diameter is $<1 \mathrm{~mm}$ after 2 days and $1.0-1.5 \mathrm{~mm}$ after 7 days on R2A agar at $20{ }^{\circ} \mathrm{C}$. Good growth occurs in liquid R2A medium and on agar plates at $1-20{ }^{\circ} \mathrm{C}$; growth is weak at $25{ }^{\circ} \mathrm{C}$ and absent at $30{ }^{\circ} \mathrm{C}$. Growth on trypticase soy agar (TSA) and nutrient agar is very weak. On R2A agar plates, grows at $\mathrm{pH} \mathrm{7-8}$ and in the presence of $0-1 \%(\mathrm{w} / \mathrm{v}) \mathrm{NaCl}$; no growth in the presence of $3 \%(\mathrm{w} / \mathrm{v})$ $\mathrm{NaCl}$. Positive for activities of cytochrome $c$ oxidase, acid phosphatase, alkaline phosphatase, esterase (C4), esterase lipase (C8), valine arylamidase, leucine arylamidase, $N$-acetyl$\beta$-glucosaminidase, naphthol-AS-BI-phosphohydrolase, $\beta$ galactosidase and $\beta$-glucosidase. Negative for indole and $\mathrm{H}_{2} \mathrm{~S}$ production, nitrate reduction and utilization of citrate and for activities of catalase, urease, protease, amylase, lysine dihydrolase, ornithine dihydrolase, arginine dihydrolase, tryptophan deaminase, lipase (C14), $\alpha$-fucosidase, $\beta$-glucuronidase and gelatinase. Assimilates D-glucose, L-arabinose, Dmannose, $\mathrm{N}$-acetylglucosamine, D-mannitol and maltose but not gluconate, citrate, malic acid, capric acid, adipic acid or phenylacetic acid. Negative for fermentation of D-glucose, Dmannitol, sucrose, inositol, sorbitol, L-rhamnose, melibiose, amygdalin and L-arabinose. The predominant cellular fatty acids are $\mathrm{C}_{18: 1} \omega 7 c$, summed feature $3\left(\mathrm{C}_{16: 1} \omega 7 c\right.$ and/or $\left.\mathrm{C}_{16: 1} \omega 6 c\right), \mathrm{C}_{16: 0}, 11$-methyl $\mathrm{C}_{18: 1} \omega 7 c$ and $\mathrm{C}_{18: 0}$. Q-10 is the major ubiquinone. The polar lipid pattern contains diphosphatidylglycerol, phosphatidylglycerol, five unknown glycolipids and six unknown polar lipids. The $\mathrm{G}+\mathrm{C}$ content of DNA of the type strain is $61.4 \mathrm{~mol} \%$.

The type strain is $\mathrm{Cr} 7-05^{\mathrm{T}}\left(=\mathrm{DSM} 22950^{\mathrm{T}}=\mathrm{CGMCC}\right.$ $1.10210^{\mathrm{T}}=$ CIP $110130^{\mathrm{T}}$ ), isolated from glacier cryoconite collected from the Pitztaler Jöchler glacier in the Oetztaler Alps, Austria. 


\section{Description of Devosia glacialis sp. nov.}

Devosia glacialis (gla.ci.a'lis. L. fem. adj. glacialis icy, full of ice, referring to the frozen, icy environment from which the type strain was isolated).

Cells are aerobic, Gram-staining-negative, motile (polar flagellation; Supplementary Fig. S3) and rod-shaped (0.6$0.8 \times 1.5-2.0 \mu \mathrm{m}$ after 2 days and $0.8-1.0 \times 1.5-2.0 \mu \mathrm{m}$ after 7 days at $20{ }^{\circ} \mathrm{C}$ on $\mathrm{R} 2 \mathrm{~A}$ agar plates). Colonies on R2A agar are light pink, convex, smooth and round with entire margins and produce slime. Colony diameter is about $1 \mathrm{~mm}$ after 7 days on R2A agar at $20{ }^{\circ} \mathrm{C}$. Good growth occurs in liquid R2A medium and on agar plates at $1-20{ }^{\circ} \mathrm{C}$; growth is absent at $30^{\circ} \mathrm{C}$. Growth on TSA and nutrient agar is absent. On R2A agar plates, grows well at $\mathrm{pH} \mathrm{7-8}$ and in the presence of $0-2 \%(\mathrm{w} / \mathrm{v}) \mathrm{NaCl}$; no growth occurs in the presence of $3 \%(\mathrm{w} / \mathrm{v}) \mathrm{NaCl}$. Positive for nitrate reduction and for activities of cytochrome $c$ oxidase, catalase, urease, acid phosphatase, alkaline phosphatase, esterase (C4), esterase lipase (C8), valine arylamidase, leucine arylamidase, $N$-acetyl- $\beta$-glucosaminidase, naphthol-AS-BI-phosphohydrolase, $\beta$-galactosidase, $\alpha$-glucosidase and $\beta$-glucosidase. Negative for indole and $\mathrm{H}_{2} \mathrm{~S}$ production, utilization of citrate and activities of lysine dihydrolase, ornithine dihydrolase, arginine dihydrolase, tryptophan deaminase, $\alpha$-fucosidase, $\beta$ glucuronidase, gelatinase, protease and amylase. Does not assimilate D-glucose, L-arabinose, D-mannose, D-mannitol, maltose, gluconate, $\mathrm{N}$-acetylglucosamine, citrate, malic acid, capric acid, adipic acid or phenylacetic acid. Negative for fermentation of D-glucose, D-mannitol, sucrose, inositol, sorbitol, L-rhamnose, melibiose, amygdalin and L-arabinose. The predominant cellular fatty acids are $\mathrm{C}_{18: 1} \omega 7 c$, summed feature $3\left(\mathrm{C}_{16: 1} \omega 7 c\right.$ and/or $\left.\mathrm{C}_{16: 1} \omega 6 c\right), \mathrm{C}_{16: 0}$ and $\mathrm{C}_{14: 0}$. Q-10 is the major ubiquinone. The polar lipids contain diphosphatidylglycerol, phosphatidylglycerol, three unknown glycolipids and three unknown polar lipids. The $\mathrm{G}+\mathrm{C}$ content of DNA of the type strain is $63.6 \mathrm{~mol} \%$.

The type strain is Cr4-44 ${ }^{\mathrm{T}}$ (=CGMCC $1.10691^{\mathrm{T}}=\mathrm{LMG}$ $\left.26051^{\mathrm{T}}\right)$, isolated from glacier cryoconite collected from the Pasterze glacier/Großglockner in the Hohe Tauern, Austria.

\section{Acknowledgements}

R. M. thanks the 'Aktion D. Swarovski \& Co. 2009' at the University of Innsbruck for financial support. We are grateful to W. Salvenmoser (Institute of Zoology, University of Innsbruck) for performing transmission electron microscopy and we thank P. Thurnbichler and J. Mair for technical assistance.

\section{References}

Bautista, V. V., Monsalud, R. G. \& Yokota, A. (2010). Devosia yakushimensis sp. nov., isolated from root nodules of Pueraria lobata (Willd.) Ohwi. Int J Syst Evol Microbiol 60, 627-632.

Brosius, J., Palmer, M. L., Kennedy, P. J. \& Noller, H. F. (1978). Complete nucleotide sequence of a $16 \mathrm{~S}$ ribosomal RNA gene from Escherichia coli. Proc Natl Acad Sci U S A 75, 4801-4805.
Cavicchioli, R. (2006). Cold-adapted archaea. Nat Rev Microbiol 4, 331-343.

Chun, J., Lee, J.-H., Jung, Y., Kim, M., Kim, S., Kim, B. K. \& Lim, Y. W. (2007). EzTaxon: a web-based tool for the identification of prokaryotes based on $16 \mathrm{~S}$ ribosomal RNA gene sequences. Int J Syst Evol Microbiol 57, 2259-2261.

Collins, M. D. (1985). Isoprenoid quinone analysis in classification and identification. In Chemical Methods in Bacterial Systematics, pp. 267-287. Edited by M. Goodfellow \& D. E. Minnikin. London: Academic Press.

De Ley, J., Cattoir, H. \& Reynaerts, A. (1970). The quantitative measurement of DNA hybridization from renaturation rates. Eur $J$ Biochem 12, 133-142.

Feller, G. \& Gerday, C. (2003). Psychrophilic enzymes: hot topics in cold adaptation. Nat Rev Microbiol 1, 200-208.

Felsenstein, J. (2009). PHYLIP (phylogeny inference package), version 3.69. Distributed by the author. Department of Genome Sciences, University of Washington, Seattle, USA.

Foster, J. W. (1944). Microbiological aspects of riboflavin. I. Introduction. II. Bacterial oxidation of riboflavin to lumichrome. J Bacteriol 47, 27-41.

Huß, V. A. R., Festl, H. \& Schleifer, K. H. (1983). Studies on the spectrophotometric determination of DNA hybridization from renaturation rates. Syst Appl Microbiol 4, 184-192.

Kates, M. (1986). Techniques of Lipidology, 2nd edn. Amsterdam: Elsevier.

Kimura, M. (1980). A simple method for estimating evolutionary rates of base substitutions through comparative studies of nucleotide sequences. J Mol Evol 16, 111-120.

Kumar, M., Verma, M. \& Lal, R. (2008). Devosia chinhatensis sp. nov., isolated from a hexachlorocyclohexane $(\mathrm{HCH})$ dump site in India. Int J Syst Evol Microbiol 58, 861-865.

Lee, S. D. (2007). Devosia subaequoris sp. nov., isolated from beach sediment. Int J Syst Evol Microbiol 57, 2212-2215.

Margesin, R. (2009). Effect of temperature on growth parameters of psychrophilic bacteria and yeasts. Extremophiles 13, 257-262.

Margesin, R., Gander, S., Zacke, G., Gounot, A. M. \& Schinner, F. (2003). Hydrocarbon degradation and enzyme activities of coldadapted bacteria and yeasts. Extremophiles 7, 451-458.

Margesin, R., Schinner, F., Marx, J. C. \& Gerday, C. (editors) (2008). Psychrophiles: from Biodiversity to Biotechnology. Berlin \& Heidelberg: Springer.

Morita, R. Y. (1975). Psychrophilic bacteria. Bacteriol Rev 39, 144-167. Nakagawa, Y., Sakane, T. \& Yokota, A. (1996). Transfer of "Pseudomonas riboflavina" (Foster 1944), a gram-negative, motile rod with long-chain 3-hydroxy fatty acids, to Devosia riboflavina gen. nov., sp. nov., nom. rev. Int J Syst Bacteriol 46, 16-22.

Reasoner, D. J. \& Geldreich, E. E. (1985). A new medium for the enumeration and subculture of bacteria from potable water. Appl Environ Microbiol 49, 1-7.

Rivas, R., Willems, A., Subba-Rao, N. S., Mateos, P. F., Dazzo, F. B., Kroppenstedt, R. M., Martínez-Molina, E., Gillis, M. \& Velázquez, E. (2003). Description of Devosia neptuniae sp. nov. that nodulates and fixes nitrogen in symbiosis with Neptunia natans, an aquatic legume from India. Syst Appl Microbiol 26, 47-53.

Ryu, S. H., Chung, B. S., Le, N. T., Jang, H. H., Yun, P.-Y., Park, W. \& Jeon, C. O. (2008). Devosia geojensis sp. nov., isolated from dieselcontaminated soil in Korea. Int J Syst Evol Microbiol 58, 633-636.

Saitou, N. \& Nei, M. (1987). The neighbor-joining method: a new method for reconstructing phylogenetic trees. Mol Biol Evol 4, 406-425. 
Sambrook, J., Fritsch, E. F. \& Maniatis, T. (1989). Molecular Cloning: a Laboratory Manual, 2nd edn. Cold Spring Harbor, NY: Cold Spring Harbor Laboratory.

Sasser, M. (1990). Identification of bacteria by gas chromatography of cellular fatty acids, MIDI Technical Note 101. Newark, DE: MIDI Inc.

Stackebrandt, E. \& Goebel, B. M. (1994). Taxonomic note: a place for DNA-DNA reassociation and $16 \mathrm{~S}$ rRNA sequence analysis in the present species definition in bacteriology. Int J Syst Bacteriol 44, 846-849.

Tamura, K., Dudley, J., Nei, M. \& Kumar, S. (2007). MEGA4: molecular evolutionary genetics analysis (MEGA) software version 4.0. Mol Biol Evol 24, 1596-1599.

Thompson, J. D., Gibson, T. J., Plewniak, F., Jeanmougin, F. \& Higgins, D. G. (1997). The CLUSTAL_X windows interface: flexible strategies for multiple sequence alignment aided by quality analysis tools. Nucleic Acids Res 25, 4876-4882.

Vannini, C., Rosati, G., Verni, F. \& Petroni, G. (2004). Identification of the bacterial endosymbionts of the marine ciliate Euplotes magnicirratus (Ciliophora, Hypotrichia) and proposal of 'Candidatus Devosia euplotis'. Int J Syst Evol Microbiol 54, 1151-1156.

Vanparys, B., Heylen, K., Lebbe, L. \& De Vos, P. (2005). Devosia limi sp. nov., isolated from a nitrifying inoculum. Int J Syst Evol Microbiol 55, 1997-2000.
Verma, M., Kumar, M., Dadhwal, M., Kaur, J. \& Lal, R. (2009). Devosia albogilva sp. nov. and Devosia crocina sp. nov., isolated from a hexachlorocyclohexane dump site. Int J Syst Evol Microbiol 59, 795799.

Wayne, L. G., Brenner, D. J., Colwell, R. R., Grimont, P. A. D., Kandler, O., Krichevsky, M. I., Moore, L. H., Moore, W. E. C., Murray, R. G. E. \& other authors (1987). Report of the ad hoc committee on reconciliation of approaches to bacterial systematics. Int J Syst Bacteriol 37, 463-464.

Wu, C., Lu, X., Qin, M., Wang, Y. \& Ruan, J. (1989). Analysis of menaquinone compound in microbial cells by HPLC. Microbiology [English translation of Microbiology (Beijing)] 16, 176-178.

Yoo, S.-H., Weon, H. Y., Kim, B. Y., Hong, S.-B., Kwon, S.-W., Cho, Y.-H., Go, S.-J. \& Stackebrandt, E. (2006). Devosia soli sp. nov., isolated from greenhouse soil in Korea. Int J Syst Evol Microbiol 56, 2689-2692.

Yoon, J.-H., Kang, S.-J., Park, S. \& Oh, T.-K. (2007). Devosia insulae sp. nov., isolated from soil, and emended description of the genus Devosia. Int J Syst Evol Microbiol 57, 1310-1314.

Zhang, D.-C., Redzic, M., Schinner, F. \& Margesin, R. (2011). Glaciimonas immobilis gen. nov., sp. nov., a member of the family Oxalobacteraceae isolated from alpine glacier cryoconite. Int $J$ Syst Evol Microbiol 61, 2186-2190. 